УДК 342.925:347.91(477)

\author{
C. B. Ківалов
}

\title{
ПРИМИРЕННЯ В ПУБЛІЧНО-ПРАВОВИХ СПОРАХ ЯК НАСЛІДОК МЕДІАТИВНИХ ПРОЦЕДУР
}

Черговий етап реформування системи правосуддя в Україні актуалізує розвиток альтернативних процедур урегулювання правових спорів, серед яких спори публічно-правового характеру посідають особливе місце. Поширення медіації на публічно-правові спори, попри негативне сприйняття окремих фахівців, саме сьогодні може стати додатковим кроком до розвитку рівноправних відносин людини та влади, забезпечити гнучкість під час вирішення конфліктів, створити атмосферу взаємної довіри. Допустимість урегулювання публічно-правового спору на основі компромісу підтверджується кількістю угод про примирення між сторонами адміністративного судочинства, яка щороку демонструє позитивну динаміку. Крім того, саме компромісні рішення стають найбільш актуальними в кризових умовах, що підтверджується періодичним запровадженням відповідних повноважень суб’єктів влади в податковій чи митній сферах під час проведення реформ або суттєвого спаду економічної активності в країні. Отже, з огляду на переваги несудових форм урегулювання спорів доцільність застосування медіативних процедур урегулювання публічно-правових спорів на сучасному етапі стає очевидною. Водночас специфіка конфліктів, що виникають у публічно-правовій сфері, вимагає виважених рішень під час визначення умов і підстав примирення, його правових наслідків. Таким чином, питання 3'ясування сутності примирення в публічно-правових спорах, його особливостей, меж, процедури й форми є надзвичайно актуальними.

Варто зазначити, що проблематика примирення в публічно-правових спорах вивчається переважно в межах відповідного інституту адміністративного судочинства. У цій сфері вагомі напрацювання мають В. Бевзенко, Г. Ткач, О. Гріненко, М. Тупічев, Ю. Кольченко, Л. Юхтенко та інші науковці. Специфіка позасудового примирення в публічно-правових споpax лише починає опрацьовуватись українськими дослідниками, зокрема С. Білугою, О. Белінською, В. Кузьмишиною, М. Мельником, С. Осятинським, К. Продіусом. Більшість авторів розглядають проблему припинен- 
ня в публічно-правових спорах, грунтуючись на перших результатах експериментально запровадженої процедури досудового врегулювання, що здійснюється на базі адміністративних судів та має виражений зв'язок із судочинством. Проте все частіше визнається за доцільне повне відділення від судової системи та переведення в категорію класичних медіативних процедур.

Нові форми врегулювання публічно-правових спорів вимагають визначення сутності примирення в публічно-правових спорах, його особливостей, меж, форми закріплення досягнутого результату та його правових наслідків. Вирішенню саме цих питань присвячено публікацію.

Мирова угода є одним із найбільш швидких і взаємоприйнятних способів вирішення конфлікту, що виник між сторонами, оскільки такий спір припиняється за вільним волевиявленням сторін та, як правило, не залишає в них почуття невдоволеності [3, с. 67]. На практиці наявні два види мирових угод: позасудові мирові угоди та судові мирові угоди. Перший вид угоди полягає в тому, що вона укладається сторонами спору без звернення до суду та $є$ угодою про вирішення матеріально-правового спору «на взаємовигідних для сторін умовах» [5, с. 518]. Варто зазначити, що поняття мирової угоди відоме досить давно й зустрічається майже в усіх правових системах. Однак зміст, що вкладається в нього, різниться залежно від конкретної правової системи та країни, у якій це явище реалізується. Відмінності можуть стосуватись майже всіх елементів мирової угоди: від самої назви до суб’єкта, об’єкта, процедури й стадії процесу, на яких дозволяється ії застосування.

Об’єкти мирової угоди зазнають певних варіацій відповідно до законодавства конкретної держави. Так, у Японії мирова угода може укладатися з усіх видів цивільних і сімейних спорів, в Іспанії обмеження щодо примирення торкаються деяких питань сімейного права, пов'язаних з особистим статусом особи, фінансових питань. Система ж так званого загального права дає можливість досягти мирової угоди щодо відшкодування збитків. Суд може приймати мирову угоду без дослідження іiі справедливості та добросовісності сторін, однак із цього правила існують винятки. Зокрема, у США суд має обов'язково затвердити договір про врегулювання спірної ситуації за позовами неповнолітніх чи недієздатних осіб, декількох осіб, певних довірених осіб тощо. У деяких країнах Західної Європи існує практика внесення факту укладення мирової угоди до протоколів судового засідання, а витяг із такого протоколу має силу судового рішення та видається на вимогу сторін. Така процедура застосовується в таких країнах, як Франція, Іспанія, Нідерланди, подібне правило можна знайти також у законодавстві Японії [1, с. 189].

Отже, незважаючи на відносну простоту інституту мирової угоди, можна говорити про складність іiі природи, яку варто вважати подвійною: як угоду між сторонами про завершення спору, наслідки якої необхідно розглядати з позиції принципів договірного права, та як різновид судового рішення про врегулювання матеріальних правовідносин. Як стверджує 
О. Гріненко, природа мирової угоди залишається подвійною, проте з вагомим ухилом до виду судового рішення, яке має бути гарантоване Державною виконавчою службою України та Законом України «Про виконавче провадження» [5, с. 519]. Отже, інститут мирової угоди має на меті прискорення судового розгляду з найменшими втратами для сторін спору, характеризується подвійною природою та $є$ своєрідним показником прозорості й рівня демократизації судового процесу певної держави. За належного механізму реалізації цього інституту він може впливати на скорочення часу, ефективність і дієвість судового розгляду [6, с. 11].

У справах, що розглядаються в адміністративному порядку, можливе своєрідне досягнення сторонами згоди у формі мирової угоди. Так, у процесі розгляду справи щодо порушення законодавства про захист економічної конкуренції Антимонопольним комітетом України стосовно дій з ознаками недобросовісної конкуренції сторони, які беруть участь у справі, можуть досягти згоди щодо певних вимог, що становлять предмет заяви про захист від недобросовісної конкуренції, та/або наступних дій сторін. Ця згода може мати вигляд мирової угоди, яка подається на розгляд Антимонопольному комітету України, і братись ним до уваги під час винесення рішення за справою. Можна навести приклад успішного досягнення мирової угоди сторонами, які брали участь у справі про порушення законодавства щодо захисту економічної конкуренції, якщо вона стає недобросовісною. Так, сторони взяли на себе взаємні зобов'язання, що привело, з одного боку, до зменшення розміру штрафу, накладеного Антимонопольним комітетом України на порушника, а з іншого - до добровільного виконання порушником узятих на себе зобов'язань, у тому числі припинення дій, які є недобросовісною конкуренцією, та повідомлення правовласнику всіх даних щодо таких дій. Зокрема, порушник зобов'язався припинити виробництво, виготовлення, продаж, рекламу, просування на ринок товарів, маркованих оспорюваним позначенням, з використанням відповідних упаковок, а також знищити всі залишки таких товарів, що були в нього.

На думку Г. Тимченко, необхідно звернути увагу на найважливіші питання примирення сторін. Перша група питань пов'язується з визначенням місця процедур примирення в процесуальному законодавстві. Для надання примиренню загальнопроцесуального значення необхідні внести відповідні зміни до ст. 1 Цивільного процесуального кодексу України (далі - ЦПКУ), ст. 2 Кодексу адміністративного судочинства України (далі - КАСУ), ст. 5 Господарського процесуального кодексу України. Крім наведених у цих нормах завдань судочинства, має бути ще одне - сприяння примиренню сторін на будь-якій стадії судового процесу. Розвиток процесуального законодавства в цій частині має йти в напрямі запровадження окремих засідань або конкретних (відокремлених) процесуальних заходів (процедур), метою яких $€$ винятково врегулювання спору й примирення сторін. У зв'язку із цим не можна погодитись із думкою Н. Бондаренко-Зелінської, яка, досліджуючи процесуальні дії судді щодо підготовки справ, дійшла висновку, що виконання дій щодо врегулювання спору має відбуватись 
у попередньому судовому засіданні після вирішення всіх інших завдань підготовки [2]. О. Носирєва, вивчаючи досвід США в альтернативному вирішенні спорів, не випадково наводила різні приклади співвідношення діяльності суду щодо примирення сторін і самої підготовки справи до судового розгляду. Науковець вказувала, що врегулювання конфлікту може передувати діям щодо підготовки справи або, навпаки, обидва напрями діяльності можуть виконуватись паралельно [11, с. 12].

Для врегулювання спору важливе значення має волевиявлення сторін, точніше, свобода під час вибору своїх можливих дій. Фактично це вибір між проведенням суворо формалізованого судового розгляду з його багаторазовими відкладеннями й перервами та використанням процедур урегулювання спору; у разі вибору останніх зводиться нанівець конфлікт сторін і заощаджуються їхні час, кошти й сили. Можливість такого вибору повністю співвідноситься з принципом диспозитивності, є навіть розширенням його дії.

Світова практика знає десятки різних примирних процедур, до яких належать переговори, посередництво, арбітраж, посередництво-арбітраж, примирне провадження, міні-суд, незалежна експертиза для встановлення фактичних обставин справи, омбудсмен, приватна судова система тощо $[15$, с. $30 ; 13$, с. 6$]$. Тобто в законодавця та сторін є великий вибір процедур, що дають змогу досягти примирення, тому немає необхідності «зациклюватись» на мирових угодах. Міжнародна спільнота знає багато шляхів вирішення цих проблем. Бажання сторін звернутись до альтернативних судочинству процедур є головною передумовою. Незважаючи на те, що сьогодні досудове врегулювання публічно-правових спорів активно «популяризується», судді часто висловлюють пропозиції особам, які беруть участь у справі в адміністративному судочинстві, скористатися цим нововведенням, проте лише для усвідомлення учасниками процесу перспективності такого вибору, його корисності для обох сторін. У зв'язку із цим можна навести думку I. Захар'янцевої: «Укладення мирових угод будь-яким чином заохочується законодавцем. На суд покладається обов'язок схиляти сторони до миру. Це заохочення мирових угод пояснюється бажанням законодавця припиняти спори та сприяти соціальному миру» [7, с. 143].

Отже, воля сторін - основна рушійна сила примирювального процесу. Тому в процесуальному законодавстві необхідно вказати на можливість проведення врегулювання спору та примирення сторін за клопотанням однієї з них, за їх взаємною згодою або за ініціативи суду. В останньому випадку також необхідне отримання згоди на проведення примирювальних процедур (наприклад, у формі фіксування цього в журналі судового засідання) [9, с. 83]. Аналогічно варто чинити в ситуації, коли клопотання про врегулювання спору заявила одна зі сторін. У зв'язку із цим дослідники слушно вказують на необхідність встановлення заборони примирення за існування заперечень іншої сторони та заборони формального підходу до проведення примирювальних процедур. 3 огляду на це ст. 113 KAСУ доцільно доповнити положенням такого змісту: «Під час підготовки справи 
до судового розгляду з метою врегулювання спору суддя у встановленому законом порядку може провести примирювальну процедуру. Примирювальна процедура проводиться за клопотанням однієї зі сторін за відсутності заперечень іншої сторони, за їх взаємною згодою або за пропозицією суду за згоди сторін» [7, с. 144]. Водночас варто зауважити, що такі зміни можуть бути доцільними лише як тимчасові на період становлення самостійної процедури досудового врегулювання публічно-правових спорів.

Важливе значення має також чітке визначення функції суду в здійсненні примирних процедур. Вважаємо, що в такому разі діï суду мають спрямовуватись не лише на координацію процесуальної діяльності сторін, забезпечення того, що врегулювання спору відбуватиметься в певній послідовності з дотриманням норм процесуального законодавства, а й на пошук за згодою сторін конкретних компромісів (поступок) кожної зі сторін та, відповідно, їх подальше формулювання й процесуальне оформлення.

Для вирішення цього завдання суду вкрай необхідно заглибитись в існуючий спір, відчути його деталі, з'ясувати подробиці, вислухати доводи кожної зі сторін, попередньо визначивши вагомість доказів сторін і правоту їніх вимог чи заперечень (цікаво, що розвиток нових технологій зумовлює й нові можливості, у тому числі щодо проведення примирення сторін в онлайн-режимі). Звичайно, не варто сподіватись, що в кожному випадку діяльність суду щодо примирення сторін досягатиме стовідсоткового успіху. Можливі ситуації, коли сторони вважатимуть вигіднішим судовий розгляд. 3 огляду на це вважаємо за доцільне законодавчо врегулювати ситуацію, коли суддя, який здійснював примирення, що не досягло позитивного результату, не може розпочинати розгляд справи по суті, оскільки вже мав можливість попередньо оцінити позицію кожної зі сторін та, напевно, висловлював свою думку щодо можливих результатів процесу. Тому пропонуємо закріпити в законодавстві положення про те, що розгляд i вирішення справи здійснює суддя, який не брав участі в примиренні сторін; при цьому необхідно буде визначити порядок передання справи, провадження в якій відкрито, від одного судді до іншого.

Наступним кроком у процесуальній «легалізації посередництва як однієї з можливих форм узгоджувальної діяльності, на думку А. Рожкової, має стати вказівка про посередника в нормі про інших учасників процесу, у зв'язку із чим ця норма може мати таку редакцію: «У судочинстві поряд з особами - учасниками справи можуть брати участь їх представники, посередники та ті особи, які сприяють здійсненню правосуддя» [16, с. 304]. Крім того, під час звернення сторін до посередника закон повинен надати право суду або зупинити провадження в справі (це вже закріплено в ст. ст. 113,156 КАСУ), або відкласти розгляд справи, а також надати можливість поновлення провадження в справі в разі недосягнення примирення [1, с. 190]. Цю пропозицію також може бути сприйнято частково, до того ж лише як «перехідний» етап.

Не можна оминути увагою позицію А. Брижинського про те, що посередництво як форма вирішення правових спорів не потребує детальної 
законодавчої регламентації, оскільки практично завжди діє поза межами судової системи. Тому, на думку вченого, питання структури, окремих процедур здійснення посередництва мають залишатись на розсуд посередника й конфліктуючих сторін, а в законодавчому порядку необхідно вирішити лише проблеми, які стосуються вимог до професійних посередників (отримання спеціальної освіти, наявність відповідної ліцензії, встановлення правил професійної етики для посередників) [4, с. 86].

На думку Г. Тимченко, процесуальне законодавство лише виграє від того, що в ньому з'являться норми, які регулюватимуть також порядок проведення на попередніх стадіях процесу примирних процедур [17, с. 96]. Певна річ, можна послатись на досвід розвинених європейських країн, говорити про те, що в них прийнято спеціальні закони про медіацію (посередництво). Однак в Україні підготовлено лише проект закону про медіацію, який уже тривалий час перебуває на стадії доопрацювання, тоді як переваги мирного врегулювання зростаючої кількості спорів є очевидними.

Результати діяльності посередника в примиренні сторін, подальша доля взаємовідносин значною мірою залежать від характеру конфіденційності такої діяльності. При цьому мова йде не лише про проведення негласного, закритого заходу (хоча законодавство не містить у цьому плані жодних обмежень принципу гласності, на нашу думку, усе-таки необхідно відповідним чином доповнити процесуальні кодекси та вказати, що проведення примирних процедур повинне мати закритий характер), а й про певні гарантіі дотримання конфіденційності, а саме про заборону розголошення інформації, яка стала відомою сторонам чи посереднику під час здійснення примирних процедур.

Деякі країни для закріплення такої заборони використовують поняття «привілей», що означає звільнення особи від обов'язку свідчити в суді. ЦПКУ та КАСУ таке поняття не містять, проте в ході дослідження доказів фактично встановлюють привілеї (абсолютні й відносні) на розголошення тих чи інших відомостей. До абсолютних привілеїв включено неможливість допиту як свідків певного кола осіб (зокрема, заборонено допитувати тих, хто згідно із законом зобов'язаний зберігати в таємниці відомості, що були довірені особі у зв'язку з іï службовим чи професійним становищем, про такі відомості; заборонено допитувати священнослужителів про відомості, отримані ними під час сповіді віруючих тощо). До захищених відносним привілеєм осіб належать такі, які за власним розсудом можуть відмовитись від свідчення в суді, наприклад, громадянин щодо самого себе, членів сім’ї чи близьких родичів (ст. ст. 51-3, 52 ЦПКУ, ст. 65 КАСУ).

Під час закріплення можливості вдатись до послуг посередника у врегулюванні спору логічно поширити привілеї на відносини, що виникають між посередником і сторонами, а також визначити, до якого виду привілеї (абсолютного чи відносного) належить ця діяльність. Варто виходити 3 того, що вибір посередника для врегулювання спору - це прямий наслідок дії принципу диспозитивності, оскільки цей вибір засновується на обопільній згоді сторін. Водночас такий підхід у сучасних умовах майже повністю 
унеможливлюється, оскільки в кожному із судів, у яких є можливість застосувати медіативне врегулювання публічно-правового спору, лише троє суддів з усього штату здійснюють цю процедуру. Крім того, в Одеському та Вінницькому окружних адміністративних судах сторони спору суддів не обирають, оскільки їх призначає голова суду.

Якщо виходити з доцільності відмежування медіативного врегулювання спору та надання статусу самостійності цій процедурі, оптимальним буде підхід, за якого сторони спору самі обиратимуть медіатора. Цього положення необхідно дотримуватись і в подальшому, тому лише за згодою сторін можуть бути розголошені відомості, про які дізнались під час проведення примирної діяльності. Отже, доказовий привілей за участю медіатора має відносний характер і прямо пов’язується з думкою сторін.

Зрештою, під час завершення діяльності щодо врегулювання спору варто передбачити варіанти процесуального оформлення отриманих результатів. Зазначимо, що це одне з найбільш гострих і неоднозначних питань. На наше переконання, не варто єдиним результатом примирення сторін вважати мирову угоду. Можливі також інші форми примирення сторін. Наприклад, якщо спір виник у зв'язку з виконанням певного договору, то примирення сторін полягатиме в укладенні іншого (нового) договору, у тому числі угоди про врегулювання спору; в окремих випадках за результатами проведення примирних процедур позивач може прийняти рішення відкликати свою заяву або суд може винести рішення на умовах, прийнятих сторонами. Для цього пропонується доповнити процесуальне законодавство, закріпивши в ньому таке положення: «Суд за клопотанням сторін у порядку, встановленому цим кодексом, виносить рішення, засноване на умовах, досягнутих у ході проведення примирних процедур» [17, с. 95]. Підкреслимо, що за умови відмежування медіативного врегулювання публічно-правових спорів жодні додаткові процесуальні механізми «засвідчення» угоди, якої досягли сторони, не потрібні.

Медіативне врегулювання спорів характеризується тим, що пошук взаємоприйнятного рішення відбувається не на основі формальних документів, а винятково з огляду на пошук балансу інтересів сторін шляхом проведення низки переговорів, висловлення думок і пропозицій за участю незалежної особи (медіатора), яка діє на засадах незалежності й неупередженості, сприяє підтримці та розвитку між сторонами культури їхніх відносин, досягненню позитивного результату та взаєморозуміння в спорі, що виник між ними.

Перевага медіаціі перед судовим вирішенням спорів полягає в таких аспектах: по-перше, суддя в межах судового процесу не має можливостей щодо застосування правил урегулювання спору, які не передбачаються конкретними нормами закону, навіть якщо ці правила взаємовигідні для обох сторін, оскільки суддя діє лише в межах, передбачених законом; по-друге, під час здійснення судочинства суддя керується законом і наявними доказами у відповідній справі. Останні він може трактувати лише як достовірні й недостовірні, оцінюючи їх на власний розсуд. У медіації будь- 
яка зі сторін може визнати, що претензії іншої сторони $є$ певною мірою обгрунтованими, та погодитись на компромісне рішення.

Варто нагадати також, що через звичайну для сучасності формальну процедуру судочинства розгляд справ затягується на місяці та навіть роки, при цьому інтереси сторін не задовольняються, тобто не забезпечуються їхні права. Непоодинокими є випадки, коли через тривалість судового процесу питання, з яких подавалися судові позови, втрачають свою актуальність, а сторони несуть суттеві матеріальні й моральні збитки та величезні втрати часу.

Л. Юхненко вважає, що в разі досягнення згоди сторони підписують мирову угоду, яка підлягає затвердженню ухвалою суду та має юридичну силу судового рішення [18, с. 111]. Однак вважається, що термін «мирова угода» в контексті медіативного врегулювання публічно-правового спору використовувати недоречно, оскільки мирова угода існує в межах адміністративного судового процесу. Тому необхідно відмежовувати мирову угоду, яку пропонує заключити суддя на підготовчій стадії адміністративного судочинства, від угоди про результати медіації, у якій медіатор $є$ посередником.

Стаття 113 KАСУ містить положення про те, що сторони можуть повністю або частково врегулювати спір на основі взаємних поступок. Примирення сторін може стосуватись лише прав та обов'язків сторін і предмета адміністративного позову. Вважаємо, що положення цієї норми стосується саме досягнення примирення в суді, адже під час застосування медіативної процедури умови угоди, межі позову та, відповідно, межі спірних домагань не є зафіксованими.

КАСУ не розкриває зміст поняття досягнення примирення й мирової угоди, проте аналіз його норм, судової практики та наукової спадщини дає змогу виокремити такі ознаки примирення:

1) це розпорядча процесуальна дія. Вимоги до особливого порядку оформлення повноважень представника (ст. ст. 58, 59 КАСУ), підвищені вимоги до процесуального оформлення цієї дії (ст. 136 КАСУ) - процесуальні гарантії, спрямовані на підвищення відповідальності осіб, які розпоряджаються правом, за наслідки своїх дій. Сторони розпоряджаються процесуальним правом на отримання захисту порушеного суб'єктивного права або інтересу позивача, що охороняється законом, і правом на захист відповідача від необгрунтованих вимог позивача за допомогою вирішення справи судом. Серед дослідників інституту примирення (мирової угоди) неоднозначно вирішено питання про те, чи відбувається під час досягнення примирення (укладення мирової угоди) розпорядження матеріальним правом або ж лише процесуальним. Більшість учених вважають, що розпорядження матеріальним правом може існувати під час досягнення примирення (укладення мирової угоди). Більше того, О. Бортнік вважає, що розпорядження матеріальним правом в акті примирення (мировій угоді) присутнє завжди, чим ця дія відрізняється від відмови від позову [3, с. 118]. Проте існує й інша позиція: у мировій 
угоді йдеться про матеріальні права, що припускаються, тому сторони розпоряджаються процесуальними правами. На розгляді суду перебувають правовідносини, що припускаються, а відмовитись можна тільки від дійсного права [8, с. 11]. Додатково можна зазначити, що суди також орієнтуються на те, що під час досягнення примирення (укладення мирової угоди) відбувається розпорядження не лише процесуальними, а й матеріальними правами, тому для здійснення розпорядчих дій потрібне спеціальне застереження в довіреності представника;

2) це процесуальна дія, спрямована на вирішення спору самими сторонами, що сперечаються, а не судом. Матеріально-правовий конфлікт за звичайного перебігу процесу вирішується судом, який оцінює законність та обгрунтованість вимог позивача й заперечень відповідача, відображає свої висновки в судовому рішенні. Досягаючи примирення (укладаючи мирову угоду), сторони спору тим самим відмовляються від перспективи вирішення їх спору судом, який може дати єдину відповідь про характер і зміст правовідносин (або про відсутність правовідносин взагалі), що склались між ними (за умови, що рішення буде законним та обгрунтованим). Результат вирішення суперечки самими сторонами може не збігатись із рішенням, яке суд виніс би, якби сторони не досягли примирення (не уклали мирову угоду). Цей висновок грунтується на аналізі норм, що містяться в ст. 136, абз. 3 ч. 1 ст. 157 КАСУ про порядок закриття провадження в справі у зв'язку з досягненням сторонами примирення (затвердженням судом умов мирової угоди);

3) для досягнення мети припинення спору сторони погоджують умови його припинення. Умови, на яких сторони згодні будувати свої взаємини, заносяться до журналу судового засідання та підписуються сторонами або застережуються в письмовій заяві суду, яка залучається до справи, на що вказується в журналі судового засідання. Важливість чіткої фіксації умов примирення (мирової угоди) обумовлює особливі вимоги до їх процесуального закріплення, відображені в ст. 136 КАСУ;

4) процесуальним документом, що оформлює закінчення справи шляхом досягнення примирення (укладення мирової угоди), є ухвала про закриття провадження в адміністративній справі. Досягнення примирення (укладення сторонами мирової угоди) веде до закінчення справи без винесення судового рішення. Проте ухвала про закриття провадження в адміністративній справі у зв'язку з досягненням примирення (укладенням мирової угоди) має наслідки судового рішення [12, с. 353] у разі відмови від виконання сторонами умов примирення (ст. ст. 14, 157, 158 КАСУ);

5) примирення (мирова угода) - продукт волевиявлення двох чи більше осіб, що є основною відмінністю від відмови позивача від позову та визнання позову відповідачем;

6) примирення (мирова угода) є юридичним фактом, що тягне припинення провадження лише в разі посвідчення його судом; у цьому полягає відмінність процесуального інституту примирення (мирової угоди) від «позасудової мирової угоди», яка фактично є звичайним матеріально-право- 
вим договором між сторонами. Затвердження примирення (мирової угоди) судом також обумовлює можливість примусового виконання умов цієї угоди в разі ухилення сторін від виконання обов'язків, передбачених нею (ст. ст. 14, 157, 158, ч. 1 ст. 258 КАСУ, п. 2 ч. 2 ст. 3 Закону України «Про виконавче провадження» від 21 квітня 1999 р. № 606-XIV [14]).

Отже, варто погодитися з О. Михайловим щодо того, що ознаки примирення (мирової угоди) сторін в адміністративній справі є такими:

- розпорядча дія;

- багатостороння (частіше двостороння) дія;

- процесуальна дія, спрямована на вирішення спору сторонами, які сперечаються, а не судом;

- процесуальна дія, що здійснюється шляхом узгодження умов, на яких сторони припиняють спір;

- затверджене судом примирення (мирова угода) є підставою для закриття провадження в адміністративній справі [10, с. 304].

Угода про результати медіативного врегулювання публічно-правового спору, що укладається в результаті означеної процедури, укладається між сторонами спору в простій письмовій формі відповідно до загальних засад адміністративного процесуального законодавства України та принципів медіативного врегулювання публічно-правового спору, містить викладення досягнутих сторонами в ході медіативного врегулювання спору спільних рішень щодо позасудового врегулювання спору та підписується всіма сторонами медіативного врегулювання спору.

Угода про результати медіативного врегулювання публічно-правового спору містить такі відомості: дату й місце укладення угоди про результати медіації найменування (для юридичних осіб) або прізвище, ім'я та по батькові за його наявності (для фізичних осіб) сторін медіативного врегулювання спору, їх місцезнаходження (для юридичних осіб) або місце проживання (для фізичних осіб); предмет публічно-правового спору; викладення рішення, досягнутого сторонами щодо медіативного врегулювання спору.

Сторони врегулювання публічно-правового спору мають право визначити в угоді про результати медіації також інші положення й домовленості сторін зазначеної процедури.

Угода про результати медіативного врегулювання публічно-правового спору укладається в кількості примірників відповідно до кількості сторін: по одному для кожної сторони та один примірник для судді-посередника (медіатора) [1, с. 190]. Угода про результати медіативного врегулювання публічно-правового спору набирає чинності в день їі затвердження суддею окружного адміністративного суду.

В угоді про результати медіативного врегулювання публічно-правового спору сторони вказують відомості, які вони вважають допустимими для використання як доказів для ознайомлення суду або можливого судового провадження. До відомостей, конфіденційність яких учасники медіативного врегулювання спору зобов'язані зберігати, належать такі дані: пропози- 
ції однієї зі сторін про застосування медіації, як і готовність однієї зі сторін до участі в зазначеній процедурі; думки чи пропозиції, які було висловлено однією зі сторін щодо можливості врегулювання публічно-правового спору; визнання певних фактів, зроблених однією зі сторін під час застосування медіації; готовність однієї зі сторін прийняти пропозицію медіатора або іншої сторони про врегулювання спору; інші відомості, а також фіксація процедури врегулювання спору.

Надзвичайно важливим питанням є визначення обов'язковості угоди про результати медіації та наслідків іiі порушення. Зауважимо, що більшість учених, які розпочали наукові розвідки щодо питань медіації, віднесених до юрисдикції адміністративних судів, наголошують на обов'язковості для виконання сторонами укладеної угоди. Водночас у жодній із публікацій не згадується питання механізмів забезпечення іiі виконання сторонами спору.

Якщо звернутись до угоди про примирення, яку укладено в адміністративному судочинстві, іiі обов'язковість гарантується положенням КАСУ, зокрема тим, що в разі невиконання умов угоди про примирення сторона має право звернутись до суду, і це $€$ підставою для поновлення провадження в справі. У примусовому порядку виконати угоду про примирення, укладену в адміністративному судочинстві, також не можна.

3 огляду на вказане, а також на базовий принцип добровільності медіації, не варто говорити про обов'язковість угоди. Якщо така угода не виконується, це означає, що медіація не досягла своєї мети, а положення, прописані в ній, не відповідають дійсному волевиявленню сторін спору.

Наголосимо, що необов'язково результатом переговорів може бути лише рішення сторін, коли одна сторона поступається певною вигодою іншій стороні та/або спір вирішується примусовими заходами. Це може бути рішення, спрямоване на майбутні правовідносини, побудовані в порядку та в спосіб, передбачені законодавством України. Підкреслимо, що вирішення спору через медіацію виступатиме не лише поступкою, а й способом заощадження державних коштів у вигляді судових витрат і витрат на примусове виконання судових рішень. Це $є$ основною відмінною ознакою процедури медіації шляхом проведення переговорів від існуючого інституту попереднього судового засідання й примирення сторін, що може бути здійснене лише в межах предмета адміністративного позову [19, с. 108].

Таким чином, для медіації є важливою відсутність обмежень або умов iii застосування щодо будь-яких публічно-правових спорів із метою експериментального виявлення зони можливого узгодження, ускладнень під час досягнення компромісу, негативного впливу на ступінь конфліктності відносин у сфері публічного управління. Такий підхід забезпечить більш точне нормативне регулювання найважливіших елементів медіації в майбутньому.

Варто відмежовувати угоди про результати медіативного врегулювання спору від угоди про примирення в адміністративному судочинстві на 
основі відмінностей правових наслідків іï порушення. 3 огляду на суто добровільну природу медіації угода про ії результати виконується сторонами з доброї волі. Відтак невиконання угоди про результати медіативного врегулювання публічно-правових спорів не може бути підставою для поновлення цієї процедури. Вважається, що процедура не досягла своєї мети та конфлікт не врегульовано, тому сторони можуть вирішити спір в адміністративному суді.

\section{Література}

1. Білуга С. Угода про примирення за наслідками досудового врегулювання адміністративно-правових спорів: особливості правової природи / С. Білуга / / Науковий вісник Міжнародного гуманітарного університету. Серія «Юриспруденція». - 2014. - № 12. - Т. 1. C. $188-191$

2. Бондаренко-Зелінська Н. Запровадження альтернативних способів врегулювання спорів: європейський досвід для України / Н. Бондаренко-Зелінська [Електронний ресурс]. - Режим доступу : http:/ / ndippp.gov.ua/Schorichnuk/BondarenkoZelinska.pdf.

3. Бортнік О. Мирова угода у цивільному судочинстві : дис. ... канд. юрид. наук : спец. 12.00.03 «Цивільне право і цивільний процес; сімейне право; міжнародне приватне право» / О. Бортнік ; Харківський нац. ун-т внутр. справ. - Х., 2007. - 227 с.

4. Брыжинский А. Альтернативное разрешение правовых споров и конфликтов в России : дисс. ... канд. юрид. наук : спец. 12.00.01 «Теория и история права и государства; история учений о праве и государстве» / А. Брыжинский ; Мордовский гос. ун-т им. Н.П. Огарева. Саранск, 2005. - 234 с.

5. Гріненко О. Порівняльний аналіз сутності мирової угоди за законодавством України та зарубіжних країн / О. Гріненко // Порівняльне правознавство: сучасний стан і перспективи розвитку : зб. матер. Міжнар. наук. симпозіуму «Дні порівняльного правознавства» (м. Київ, 8-11 квітня 2009 р.) / за ред. Ю. Шемшученка та ін. - К., 2009. - С. 518-520.

6. Давиденко Д. Мировое соглашение как средство внесудебного урегулирования частноправовых споров : автореф. дисс. ... канд. юрид. наук : спец. 12.00.03 «Гражданское право и процесс; хозяйственное право» / Д. Давиденко ; МГИМО. - М., 2004. - 22 с.

7. Захарьянцева И. К вопросу правового регулирования института мирового соглашения в арбитражном судопроизводстве / И. Захарьянцева / / Актуальные проблемы процессуальной цивилистической науки : матер. науч.-практ. конф., посвящ. 80-летию проф. М.А. Викут. Саратов : Изд-во Саратовской гос. академии права, 2003. - С. 143-144.

8. Колясникова Ю. Примирительные процедуры в арбитражном процессе : автореф. дисс. ... канд. юрид. наук : спец. 12.00.03 «Гражданское право и процесс; хозяйственное право» / Ю. Колясникова ; Уральская гос. юрид. академия. - Екатеринбург, 2009. - 26 с.

9. Медіація в адміністративних справах: досвід Херсонського центру примирення : [посібник] / за ред. А. Недбайло, О. Токаленко. - Херсон : ХМЦМІ «Ттем», 2009. - 166 с.

10. Михайлов О. Ознаки примирення сторін у справах адміністративної юрисдикції / О. Михайлов / / Актуальні проблеми держави і права : зб. наук. праць / за ред. С. Ківалова. О. : Юридична література, 2007. - Вип. 35. - С. 300-304.

11. Носырева Е. Альтернативное разрешение гражданско-правовых споров в США : автореф. дисс. ... докт. юрид. наук : спец. 12.00 .03 «Гражданское право и процесс; хозяйственное право» / Е. Носырева ; воронежский гос. ун-т. - Воронеж, 2001. - 32 с.

12. Основи адміністративного судочинства та адміністративного права : [навч. посібник] / за заг. ред. Р. Куйбіди, В. Шишкіна. - К. : Старий світ, 2006. - 256 с.

13. Паладій M. Не хочете вирішувати конфлікт у суді - зверніться до медіатора / М. Паладій, Т. Шевельова / / Інтелектуальна власність: науково-практичний журнал. - 2006. № 12. - C. 4-7.

14. Про виконавче провадження : Закон України від 21 квітня 1999 р. № 606-XIV / / Відомості Верховної Ради України. - 1999. - № 24. - Ст. 207.

15. Решетникова И. Медиация и арбитражный процесс / И. Решетникова, Ю. Колясникова / / Арбитражный и гражданский процесс. - 2007. - № 5. - С. 29-30. 
16. Рожков А. Посредник как участник примирительных процедур в арбитражном судопроизводстве / А. Рожков / / Проблемы взаимодействия отраслей частного права: доктрина и методика преподавания / под ред. Е. Носыревой, Т. Сафронова. - Воронеж : Изд-во Воронежского ун-та, 2006. - С. 301-307.

17. Тимченко Г. Процедури примирення в процесуальному законодавстві України / Г. Тимченко / / Судова апеляція. - 2010. - № 4. - С. 92-96.

18. Юхненко Л. Досудове врегулювання спору шляхом проведення переговорів за допомогою судді в адміністративному судочинстві: сутність і проблеми запровадження / Л. Юхненко // Юридичний вісник: щоквартальний журнал. - 2013. - № 3. - С. 106-112.

\section{А н о т а ц і я}

Ківалов C. В. Примирення в публічно-правових спорах як наслідок медіативних процедур. - Стаття.

У статті досліджено сутність та ознаки примирення сторін публічно-правового спору через застосування медіативних процедур. Визначено відмінності угоди про примирення в адміністративному судочинстві та за наслідками медіації. Обгрунтовано недоцільність нормативного закріплення зобов'язальних механізмів виконання угоди, досягнутої за результатами медіативного врегулювання публічно-правового спору. Проаналізовано зв'язок медіативного врегулювання спору та адміністративного судочинства з обгрунтуванням пропозиції визнати звернення сторін до медіації підставою для поновлення строку звернення до адміністративного суду.

Ключові слова: примирення, публічно-правові спори, угода про примирення, медіація, адміністративне судочинство.

\section{Анно т а ция}

Кивалов С. В. Примирение в публично-правовых спорах как следствие медиативных процедур. - Статья.

В статье исследована сущность и признаки примирения сторон публично-правового спора путем применения медиативных процедур. Определены отличия соглашения о примирении в административном судопроизводстве и в результате медиации. Обоснована нецелесообразность нормативного закрепления обязывающих механизмов выполнения соглашения, достигнутого по результатам медиативного урегулирования публично-правового спора. Проанализирована связь медиативного урегулирования спора и административного судопроизводства с обоснованием предложения признать обращение сторон к медиации основанием для восстановления срока обращения в административный суд.

Ключевые слова: примирение, публично-правовые споры, соглашение о примирении, медиация, административное судопроизводство.

\section{S u m m a r y}

Kivalov S. $V$. Reconciliation in public law disputes as a result of mediation procedures. - Article.

In the article there are researched the essence and features of the conciliation of the public-legal dispute parties' through the mediation procedures. There are defined the differences between the conciliation agreement in the administrative legal proceeding and the consequence of the mediation. There is grounded the non-expediency of the normative provision of the obligation mechanisms of the agreement execution that was achieved as a result of the mediation regulation of the public-legal dispute. There are analyzed the connection between the mediation regulation of the dispute and administrative legal proceeding with the grounded suggestion of admitting the parties appeal to mediation as a ground for restoration of the term for appeal to the administrative court.

Key words: conciliation, public-legal disputes, conciliation agreement, mediation, administrative legal proceeding. 